\title{
Contemporary Architecture in Tirana during the Transition Period
}

\author{
Florian Nepravishta
}

Faculty of Architecture and Urbanism, Polytechnic University of Tirana, Albania

\author{
Citation: Nepravishta F. Contemporary Architecture in Tirana during the \\ Transition Period. SEE J Archit Des. 2016 May 12; 2016:1001 \\ Keywords: contemporary architecture; international style; \\ postmodernism; transition; Tirana. \\ Correspondence: Florian Nepravishta. Faculty of Architecture and \\ Urbanism, Polytechnic University of Tirana, Albania. E-mail: \\ florian.nepravishta@fau.edu.al \\ Received: 06-Feb-2016; Revised: 29-Feb-2016; Accepted: 01-Mar- \\ 2016; Published: 12-May-2016 \\ Copyright: ๑ 2016 Florian Nepravishta. This is an open-access article \\ distributed under the terms of the Creative Commons Attribution License \\ medium, provided the original author and source are credited. \\ Competing Interests: The author has declared that no competing \\ interests exist.
}

\begin{abstract}
AIM: Tirana is a city that in transition period has been changed and transformed both architecturally and in its urban form.

MATERIAL AND METHODS: Unavoidable changes in an urban rush: from unregulated spontaneous development and without infrastructure it has gone through the urban redevelopment planning and architectural projects

RESULTS: Some of the most famous European studios, from Bolles+Wilson to MVRDV, AtenaStudio, Bjarke Ingels, Archaea Studio, Grimshaw, Daniel Libeskind, are facing Tirana capital that has claimed the international architectural culture's attention.

CONCLUSION: This article draws a view of contemporary architecture produced by domestic and international architects and planners in a city looking through the new century with a will of renewa
\end{abstract} throw contemporary planning and design.

\section{Introduction}

Political and economic changes after 1991 have dramatically influenced the architecture and urban development in Albania. Socialist architecture has produced for years a rigid and standardized typology, even randomly pure and primitive architectural prototypes, except for some objects of public importance. Albanian architects guided from the socialist realism ideology were very rigid in the development of the modern ideas. After the collapse of socialism "the years 1991 - 1993 marked a crisis of identity of Albanian architecture, otherwise can be considered the beginning of a new era of the modern architecture [1]. The transition period, except the reflection in architecture, brought a period of changes in the urban planning and territory. The return of private property to the citizens has given the possibility to construct their dwellings within their property without planning and unification of housing typology.

Internal mass migration within the country in the past 25 years, a characteristic of the transition period, the movement of population from rural to urban with better lifestyle conditions, continues to be a social process unchecked, with significant consequences for the urban development of the country's major cities and in Tirana city. Inevitably, this demographic process influenced the development of urban space by random and rapid construction, disrespecting of the municipal regulations, problems with issues of traffic and transport, the absence of broad roads, lack of public spaces, difficulties in the management of water and emergency services. Architecture ended up in the hands of ordinary people who are trying to resolve their problems with a low cost, ignored the profession of architect, becoming the initiators of "informal eclectic architecture" without identity.

A good part of the construction of this period, approximately 427000 units [2] emerged in the form of illegal structures everywhere in the public or private lands, mainly on the outskirts of cities and volumes were added spontaneously to the existing buildings in urban areas. Informal settlements consisted of dwellings developed in the logic of low-cost and selfhelp architecture. 
Other constructions of this period belong to the formal sector, which includes legal developments for residential, business or industry functions [3]. Typology of mix use apartment buildings (6-12 floors), or residential complexes, can be considered as one of the innovations of this period of architecture, primarily held in Tirana and some major cities. The buildings designed for business purposes included a series of service, recreation, and tourism facilities. The quality assessment of these buildings shows a significant improvement in innovative architectural style and contemporary elements.

Albanian architecture in the transition period has exceeded cultural and conceptual ideology, as well as mental and creative uniformity of the communist regime. It is focused successfully towards a new practice of modernity and post-modernity. This approach to economic development is inevitably reflected in the architecture and urban planning [4]. The modern architecture began to consolidate with innovative ideas of architects who came into contact with Western cultural trends and currents. These new ideas were applied primarily in Tirana, from young professionals and private design studios, based on pragmatic, as well as professional architecture practice [5]. Other imputes of modernism and internationalization style was coming from abroad. Many famous international architectural and planning studios have been present in Tirana especially after the year 2000 .

\section{Development of the Modern Architecture in the Period of Communism}

Political and economic changes in Albania in the 1990s have dramatically influenced the architecture and urban development. Socialist architecture has produced for years a rigid and standardized typology, even randomly pure and primitive architectural prototypes, except for some objects of public importance. Albanian architects guided from the socialist realism ideology were very rigid in the development of the modern ideas. The collapse of socialism in the years 1991 - 1993 marked a crisis of identity of Albanian architecture; otherwise it can be considered the beginning of a new era of the modern architecture [1].

During 46-years of the communist system, as in every sphere of life, the ideology influences and was obtrusive in city planning and architecture. Albanian architecture was an open war on private initiative and was the monopoly of the party-state, mostly led by Stalinist ideology. Architecture had applied the principles of socialist realism by a local version, closed within the domestic confines, with a primitive character, rigid and standardized. The logo of the Socialist realism style "national in form and socialist in content" was always a political dogma, because there was no executive value and never helped as an instrument of design [6].

The architecture was applied in the simple forms and volumes, reducing the concept, details, construction techniques significantly, and consequently, attempting to a lower cost. Architectural typologies were focused towards residential buildings (maximum height of 4-6 floors), agrarian and industrial complexes, administrative centers, which belonged to the urban renewal interventions and expansion in the outskirts of the city. Impacts of modern architecture in Albania were observed after 60 years of Soviet rule, where the Russian model of socialist realism of classical architecture style was criticized and abandoned. "Breaking relations with the Soviet Union also brought secession without hesitation from the 'butaforia' of the Soviet architecture" [7].

Domestic architects, who raise awareness, began to move towards a new style of architecture which already began to be influenced by the West. Petraq Kolevica in 1965 wrote: "we should put in our construction principles, ideas and the best examples of modern architecture" [7]. Modernist architecture tendencies were observed especially in the period of "liberalism" in the 70s where "modern architectural style, had already become a fact" [7]. Planning of neighborhoods, housing complexes, and blocks were based on the modern urban design practice, according to the principles of the Charter of Athens, approved at the IV Congress of CIAM "[6].

In the middle of 70 s, architecture began to lose the freedom, gained partly, due to the extreme 'ideologization' undertook by Albanian Labor Party (Communist Party). Modernism was not accepted either as a philosophical concept or as artistic practice, and, therefore, no one can create anything in the modern spirit [8]. "In 1974, began the fight against bureaucracy and the fight against foreign influences in literature and arts, according to the guidelines of the notorious Plenum IV. There was no architecture from this time" [7]. The Communist Party in power criticized some architectural works like "Palace of Cubes" (Figure 1a), Cinema-theater of Fier, Library of Korça (Figure 1b) and the ATA building. Echoes of punishment of foreign influences in the Albanian construction sector were extended until the end of 1977 where have been criticized such architecture as an expression of modernism and formalism.

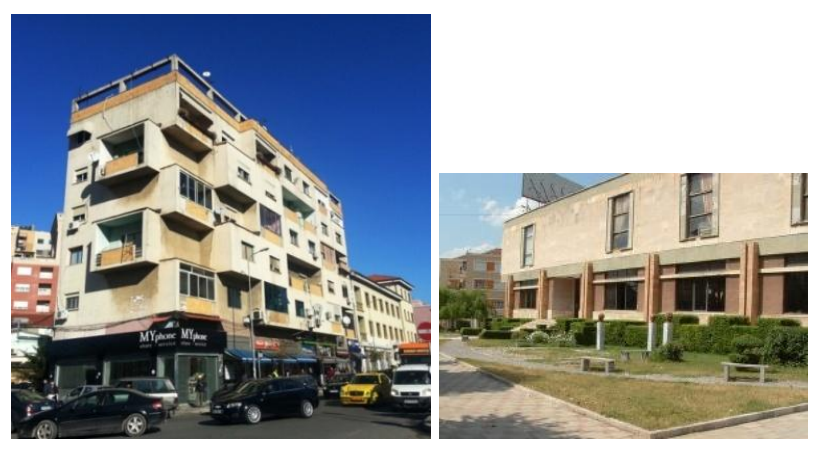

Figure 1: a) Palace of Cubes / Architect Maks Velo; b) Korça Library/Architect Petraq Kolevica [8] 
Despite the ideological obstacles and political propaganda of the regime after 1985 local architects were keen to bring innovation in the socialist realism architecture of that time, influenced by the development of European architecture. The new design of the sun, light, fresh air and greenery, saw concrete realization to the implementation of the valuable types residential typology, regarding functional, aesthetic and structural. Architecture took economic, functional, rational and simple features, based on the mechanization and the industrialization of the construction industry. The modern architecture of the communist period amounted to challenge somehow the political dictates and remains the fruit of efforts by the architects appeal and the communist oppression of censorship.

\section{Tirana - Capital of Changes in the Period of Transition}

Features of transition in Albania reflected through economic and social transformation coupled with dynamism in architectural and urban development: continually changing the city landscape, densification of the Inner City, the spread of construction everywhere in the territory, drawing the new image of the city. In this fury of changes are reflected the efforts towards modern architecture, new shapes, materials and conceptions [11]. Tirana represents mostly a general panorama of the Albanian architecture in the transition period. We can find a series of architectural styles from modernism and postmodernism till to the neo-classicism and baroque experimented by the new generation of architects that contrasted with the communist heritage. All this has happened in only 25 years, the inevitable result being a confusion of styles not only within a particular neighborhood but on a single street, and often even in a single house [10].

The new era of the city development has started with the political and economic collapse of the state apparatus in 1989 and the introduction of the democratic regime in 1991. The financial failure of some pyramidal companies in 1997 led to an overall anarchy. Between 1997 and 2001, the transition phenomenon resulted in the occupation of many open spaces and green areas of Tirana city. It was nothing more than the simple answer to a primary need to settle or the possibility to set up an essential commercial activity on no man's land, at a crucial political moment of transition, in a society that has been much closed and very rigid in her government apparatus. Above all in the suburbs, the increase of urban areas has been exponential. The town has become overcrowded, and it has grown without rules, to the limits of possibility, straining its cultural assets and its political and democratic conduction [12].

The city becomes overcrowded, and it has grown without rules to the limits of possibility, deteriorating its cultural assets and its political and democratic conduction [12].

From 2000, the city development was focused on the rehabilitating and renewing process promoted by Major Edi Rama. The uncontrolled building expansion, in all its spontaneous spatial voracity, has changed the meaning of the urban context [13]. The acceptance of the undertaken drastic solutions required a cultural change to be shared, it was necessary to recuperate a value, the meaning of "public space" and "belonging." The recovery plan of the central green area of the urban organism as the Youth Park (Parku Rinia) and the Lana River has been possible and was the first step towards recuperation of the public spaces. In another part of the city, the reality still spokes of many tiny and episodic interventions in the middle of the new informal and authorized constructions and the deteriorated existing buildings.

After a substantial impact on public space recovery, a pivotal element of a renewed and creative urban complexity, the town authorities of Tirana have extended their intervention to the renovation of the facades, trying to define the terms of redemption of the socialist heritage. Tirana was transformed into a city of art; the communist uniformity has been overturned for the difference that has been declared by the democratic evolution of Tirana and Albania [14]. The city was turned into a giant canvas where different artists and architects, from the profane to the international studios like Bolles \& Wilson [15] could express their talent (Figure $2 \mathrm{a}, \mathrm{b}$ ). In some fragments, thanks to the application of colors were achieved an attractive and modern view of their superficial expression.

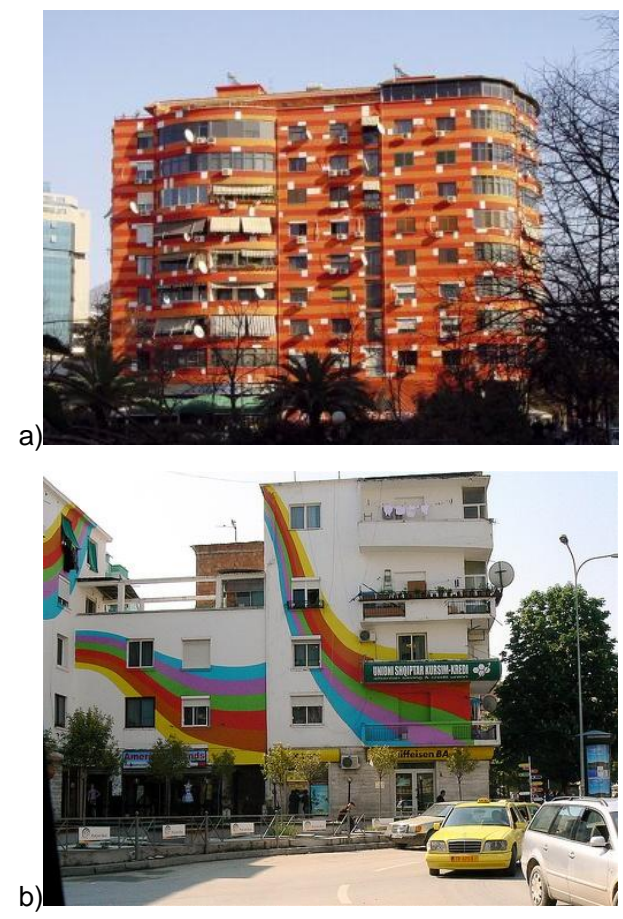

Figure 2: a) Virtual Air Conditioners/Bolles \& Willson; b) Willson Square/Municipality [15] 
What was happening to Tirana was the effect of an enormous energy at an individual, familiar and community level, that expands as a river, with no predetermined direction. This energy should not be stopped, but it should be included in the planning process of the city. The new Masterplan of Tirana was approved in 2013 (Figure 3 a, b). The polycentric Tirana was one of the main achievements of this plan.

a)

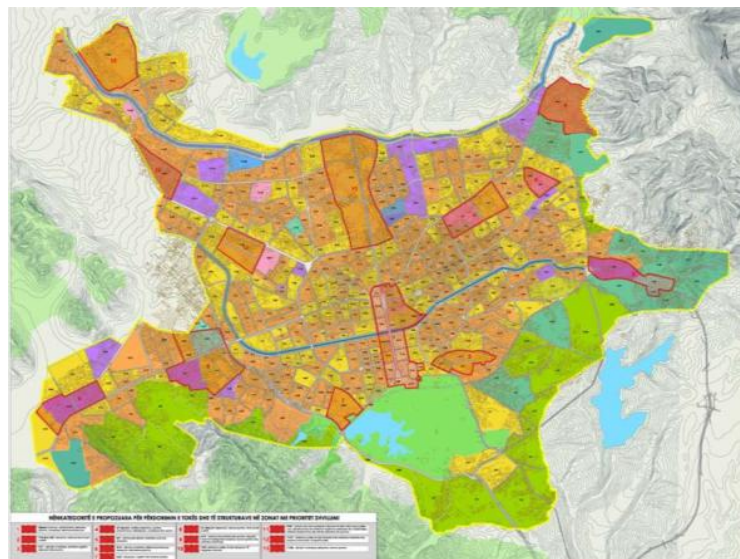

b)

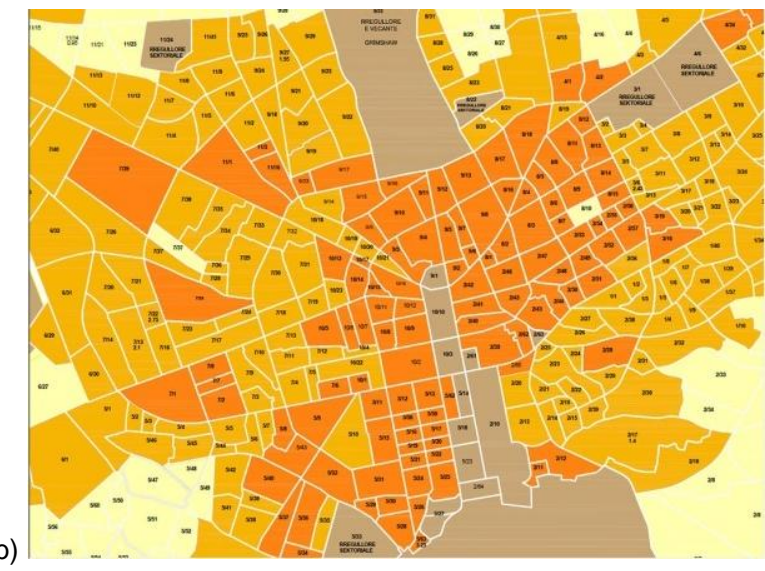

Figure 3: a) Master Plan of Tirana; b) Zoning Plan of Tirana [16]

The urban situation of Tirana remained for years full of massive concrete and brick constructions, quickly built to accommodate the exploding population, but the future appears differently. Nowadays, it has come under the spotlight of international urban development; many projects are part of a scheme to modernize the city and develop a distinct downtown core, finding a new solution for transport and other essential urban issues. Therefore, Tirana and Albania in general, have become part of new contemporary architecture influences.

\section{Contemporary Domestic Architecture in the Transition Period}

After 2000, the contribution of the Albanian architects in modern architecture is growing. Influenced by the international architecture developments and constant contact with them, they have brought in Albanian contemporary architecture a new spirit through objects designed mainly in Tirana and in other main cities. Diverse design projects and realizations of housing, schools, villas, hotels, hospitals, business centers, administrative and multifunctional buildings have been part of the creativity during the transition period, where Albanians architects were free to design, to fantasize, to be national and modern, Mediterranean and European. Authentic contemporary design projects are implemented by individuals or groups of architects in the design studio. Among the distinguish project examples of the typology of individual villas are "Flying Roof Villa" Farka (Figure 4a) and "XLT House" in Linza (Figure 5b).

a)
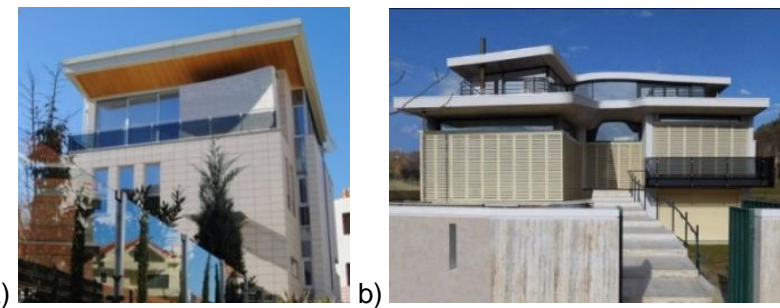

Figure 4: a) Flying roof villa, Farka/Architect Eled Fagu; b) XLT House" in Linza/Architect Skënder Luarasi [17, 18]

Other successful design projects represents the collective dwellings in Tirana. This are: "White Stone" Rezidence in "Frederik Shiroka" street (Figure 5,a); "Yellow Palace" in "Hoxha Tahsim" street (Figure 5b); "Academia" Rezidence in "Ismail Qemali" street (Figure 6); " Grameno Housing 1" (Figure 7); Residence of "Kavaja" Street and "Vila Goldi" (Figure 8); Five Housing Structures in Artificial Lake (Figure 9).

a)

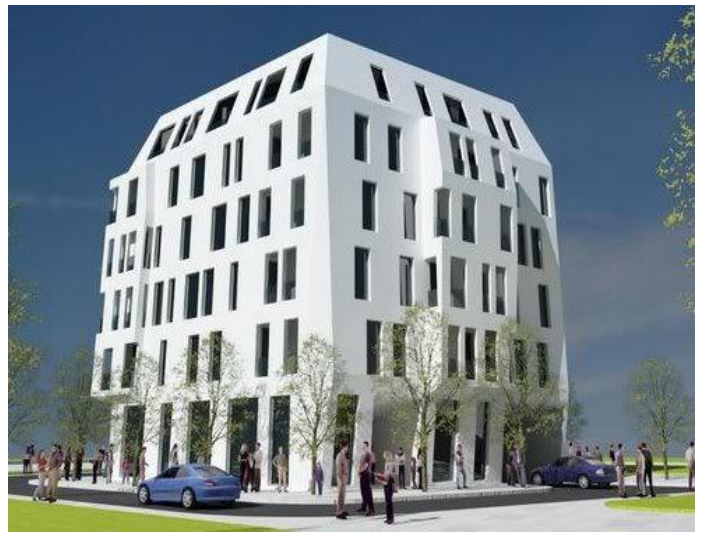

b)

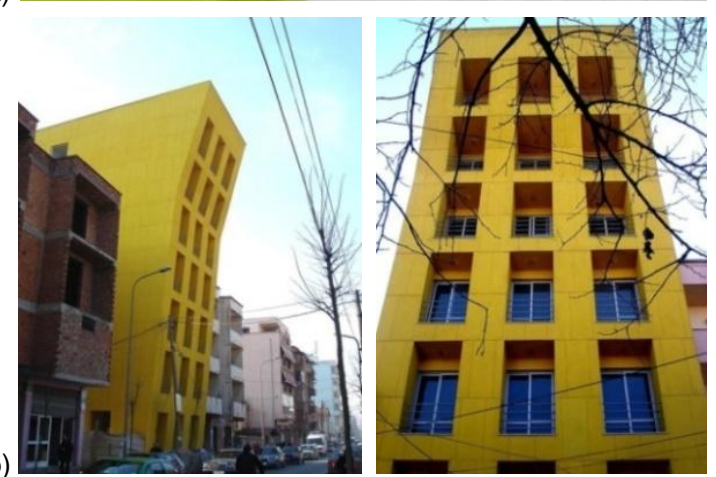

Figure 5: a) "White Stone" Residence; b) Yellow Palace / Raça Studio [20] 


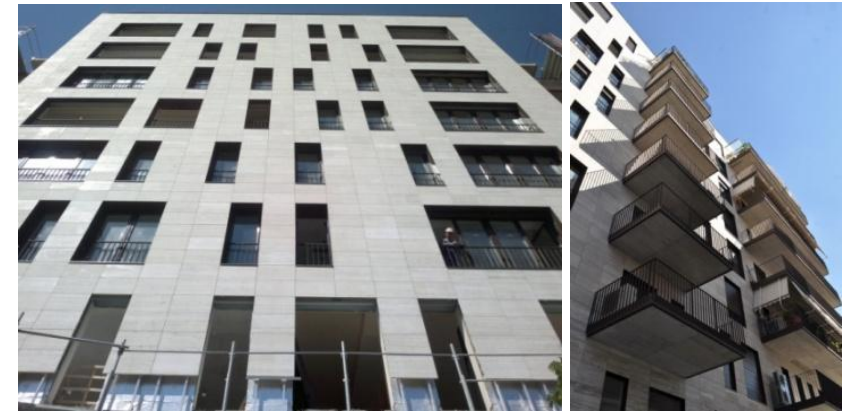

Figure 6: "Academia" Residence / B \& L Studio [21]
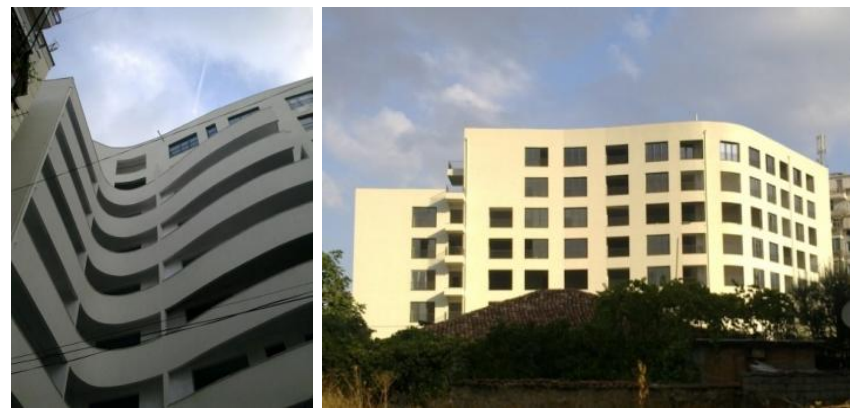

Figure 7: Grameno Housing 1/ B \& L Studio [21]
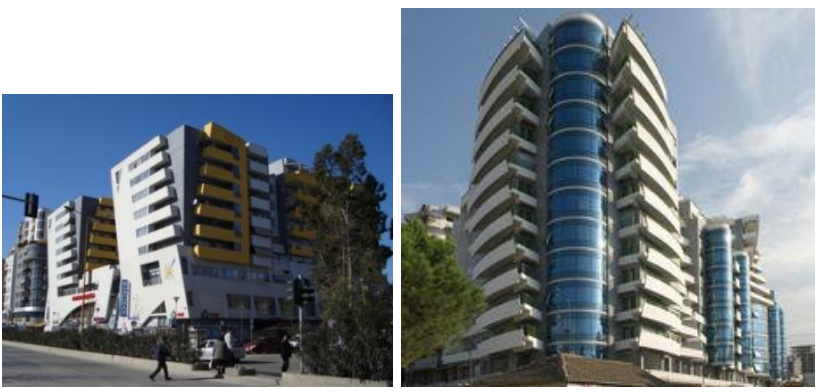

Figure 8: Residence in "Kavaja" Street and "Vila Goldi"/Architect Vladimir Bregu [22]

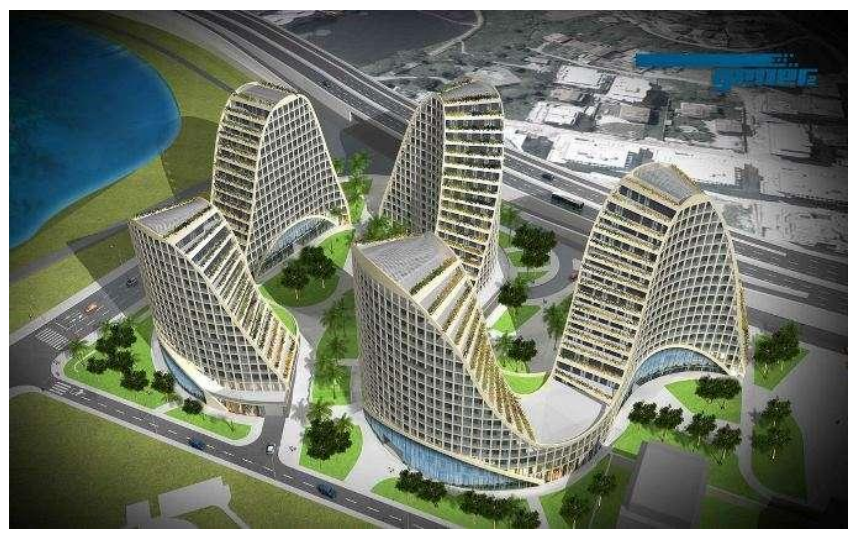

Figure 9: Five Housing Structures, Artificial Lake/Gener 2 [23]

Contemporary public facilities that reflects new architectural achievements are many, "Regional Autism Center" in Farka designed by Marin Biçoku (Figure 10). Other important projects are the industrial and retail facilities which are constructed mainly next to the main road and specifically in the corridor TiranaDurres. One example is the "Rejsi Pharma" Warehouse (Figure 11).

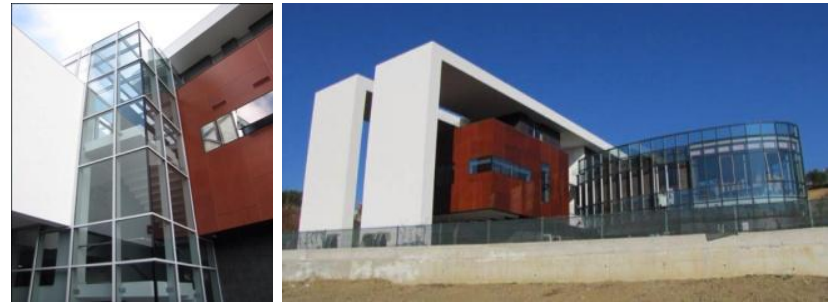

Figure 10: Regional Autism Center, Farka / Architect Marin Biçoku [24]
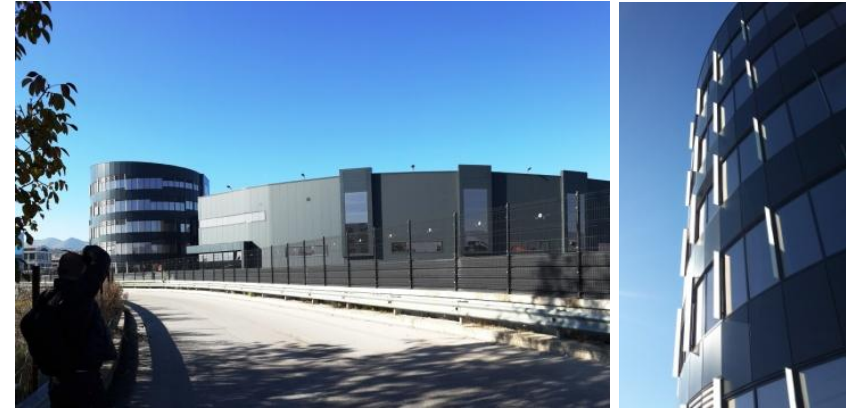

Figure 11: "Rejsi Pharma" Warehouse / Architect Florian Nepravishta [25]

\section{Modern Influences of the International Architecture}

Within the changes applied in Tirana, in an attempt to transform the urban and architectural image of the city, the municipality has invited international expertise to participate in the design of the city. Foreign architects had an active role in the first phase, primarily to educate the public and local community architects, who still bore the isolation complex of the past. Tirana developed in a chaotic manner had an immediate need for the new regulatory plan with a long-term perspective. In 2003, a call for proposals was launched for the urban plan of the Center of Tirana. The master plan of Architecture Studio, Paris, was the first step towards modern developments influenced by the EU impact. The winning project represented the existing city center premises and a new concept of contemporary urban inhabitation quarters. However, it remained in the form of an impracticable plan because it was based more on the management on parcels of the town and the clienteles' interests and not to the elements of the city and full public interest.

Compositional elements that distinguished the winner plan were ten 25-storey towers, parallel to the main boulevard, which for the first time exceeded the heights of buildings constructed by then, and bring a new architectural typology, multifunctional towers. They constitute the Tirana Center perimeter of space, 
maintain and monitor its interior, emphasizing every point of view. The plan position in space was symmetrical, axial regular, linear, equally spaced, with a dynamic silhouette, aggressive and in contrast with the volumes of existing structures (Figure 12).

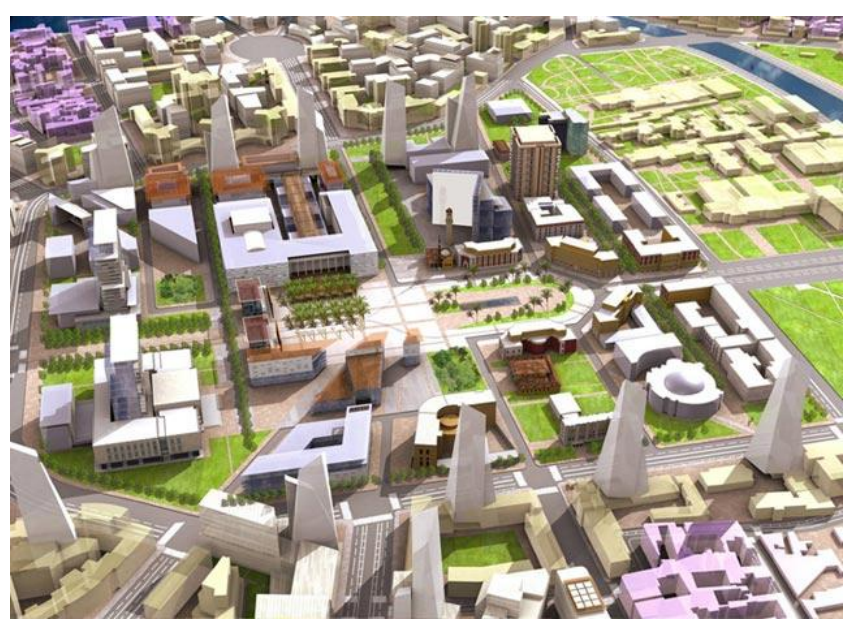

Figure 12: Tirana Center Plan/AS-Architecture Studio, Paris [26]

Another international competition was organized for the "Skanderbeg Square". Between famous studios as AS-Architecture Studio, Paris, Daniel Libeskind, Atena Studio, etc. was selected the project of joint team 51N4E Belgium and Anri Sala Albanian partner. The work for the implementation of this project continued for two years. The project has been changed (conserving all the infrastructure work of existing project) by the administration of Mayer Lulëzim Basha elected in 2013 and was finished in 2014. It was redesigned (Figure 13) in 2016 by the same team under the new administration of the Mayer Erion Veliaj.

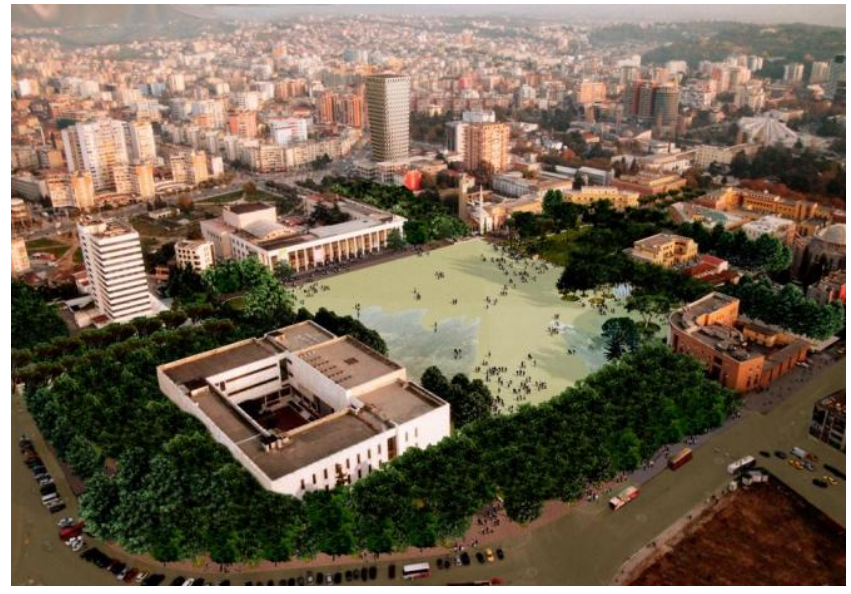

Figure 13: Skanderbeg Square/ 51N4E, Belgium \& Anri Sala [26]

Many international competitions are organized in Tirana in the years 2003-2011 for the realization of buildings part of the so-called "French Plan" of the city center. A part of the winning ideas were implemented in some high towers part of master plan. This are: Millennium Center (Figure 14a) and American
Business Center of AS-Architecture Studio, Paris, (Figure 15); "TID Tower" (Figure 14b) - designed to perceive three-dimensional, circular and square base in maximum height, rich motives of the facade of alternating tiles and glass; "4 Evergreen Tower" Archea Studio (Figure 14c) - tower inspired by the context, divided into four sections to reflect the urban design of Armando Brasini 1920; and "ABA Bussiness Center" (Polychromic Tower) redesigned by Bolles + Wilson (Figure 14d).
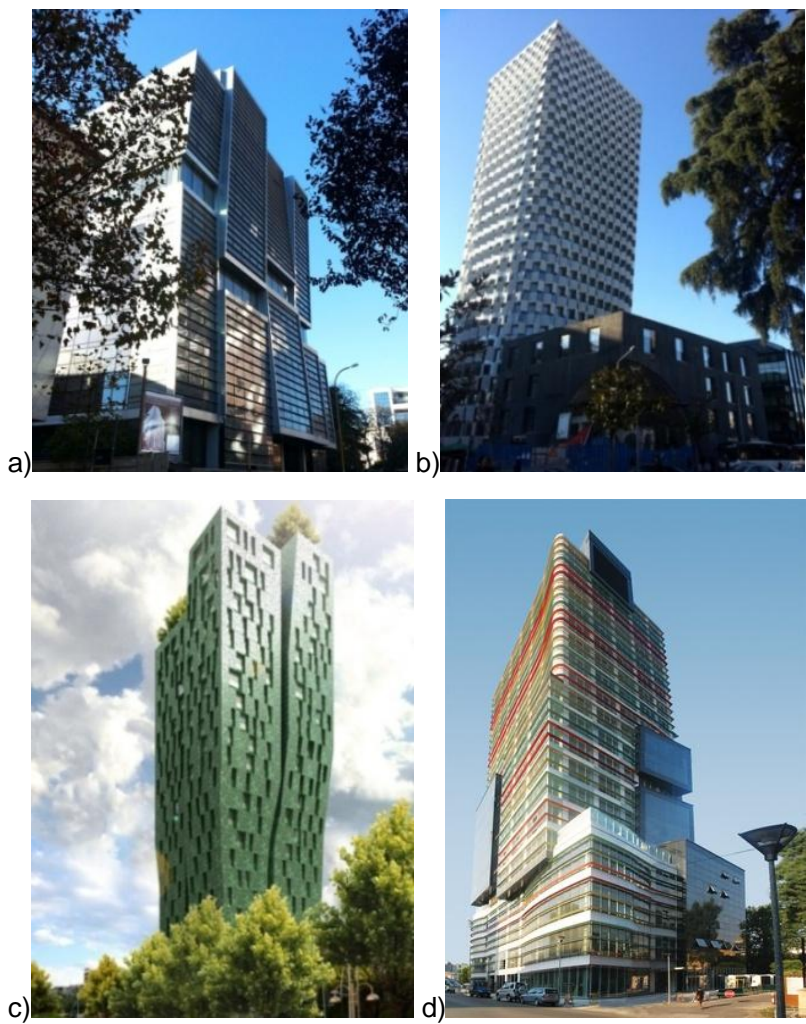

Figure 14: a) Millennium Center/ AS Architecture Studio [AU]; b) TID Tower/51N4E; c) 4Evergreen Tower/Archea Studio; d) $A B A$ Business Center/Bolles + Willson [9, 27]
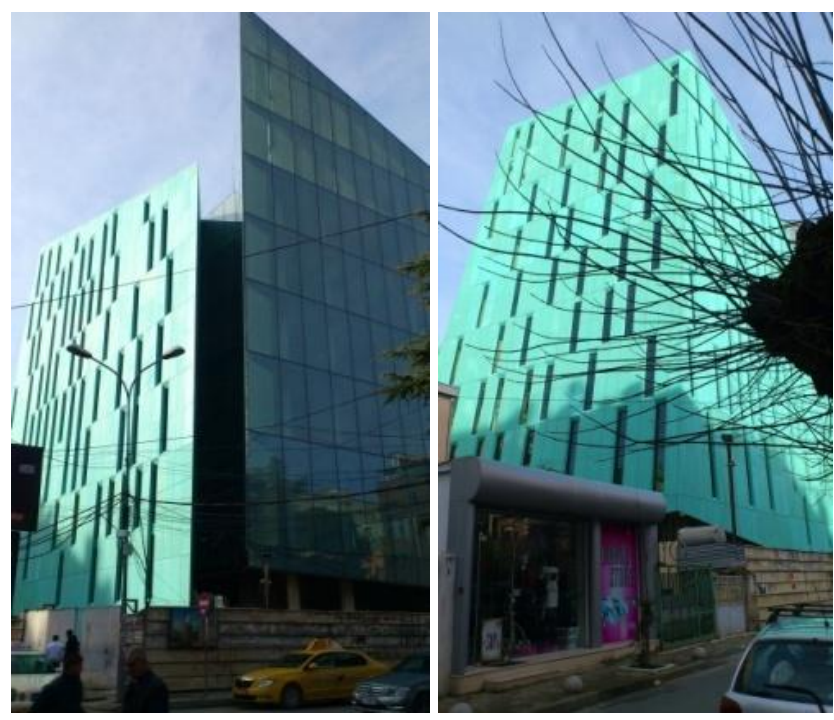

Figure 15: American Business Center/AS Architecture Studio [AU] [27] 
The facilities contain residential, commercial, service, business functions composed in high vertical constructions (some of them $85 \mathrm{~m}$ ). The new towers are easily visible and have a strong urban impact. They are treated with modern architecture style, interesting forms and volumes and high constructing technology.

Private developers in opposition to the informal housing and other informal development in the city are searching for the new concepts for real estate development (mainly of residential buildings or mix use) were the architectural quality and aesthetics play an important role for the new quality of living. They have invited to develop the architectural ideas famous architects as Daniel Libeskind, Atena Studio, Valerio Olgiati, etc. (Figure 16, 17, 18).

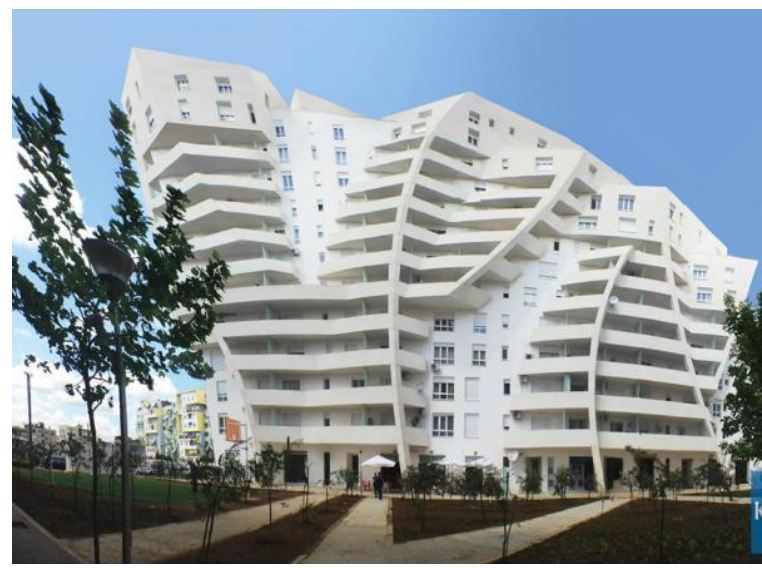

Figure 16: Libeskind Residence, Magnet/Daniel Libeskind [28]

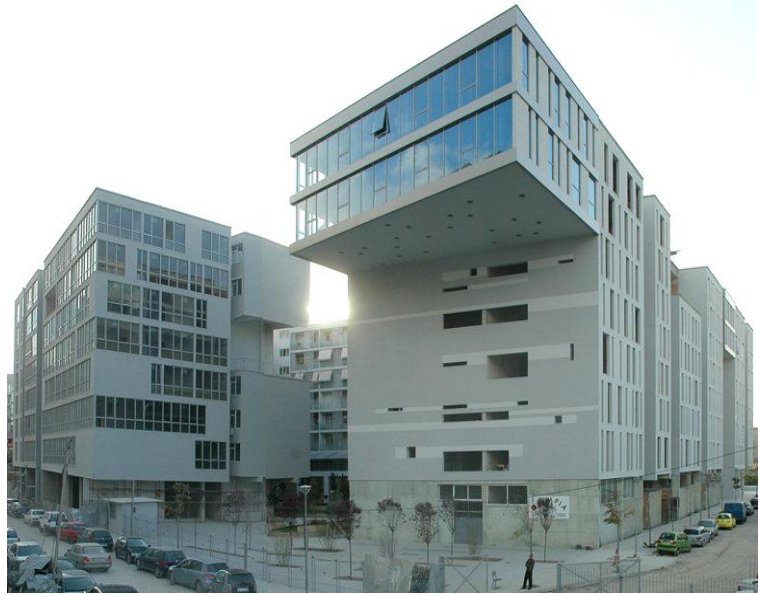

Figure 17: Le Serre/Atena Studio [9]

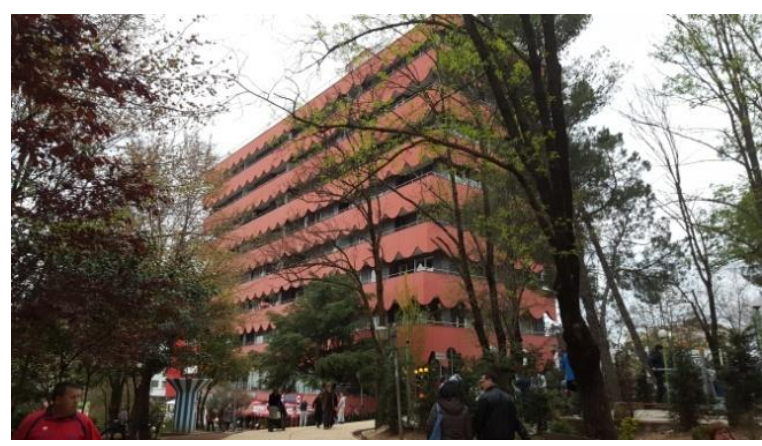

Figure 18: Adria Palace / Valerio Olgiati [9]
International design studios designed many education facilities as, "At Pjetër Mëshkalla Secondary School" designed by Francesco Scardaccione (Figure 19) and "Arsakeo of Tirana," designed by Isaias Dimitrios and Papaioannou Tasis (Figure 20).

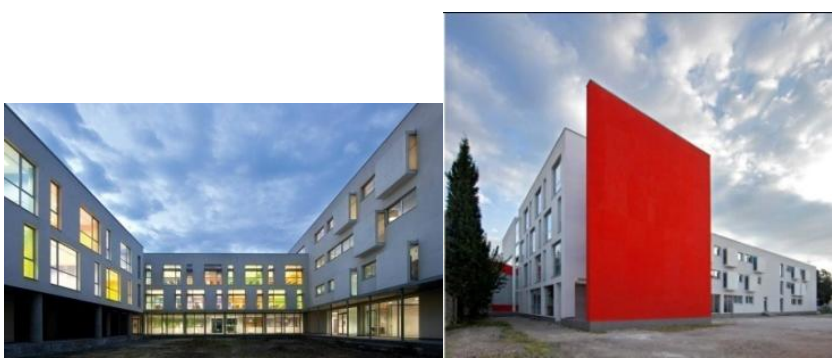

Figure 19: "At Pjeter Meshkalla" Secondary School"/Francesco Scardaccione [19]

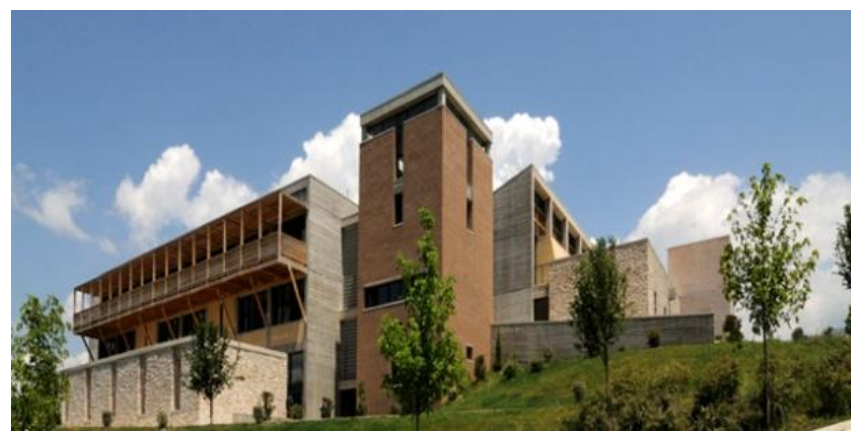

Figure 20: Arsakeo of Tirana/Isaias Dimitrios \& Papaioannou Tasis [29]

Also, in many cases, the private sector has undertaken competitions for their development projects as: "Tirana International Airport TIA" wined by the Hintan Associates (Figure 20). The terminal has increased the quality of services offered and become the modern gate to the country.

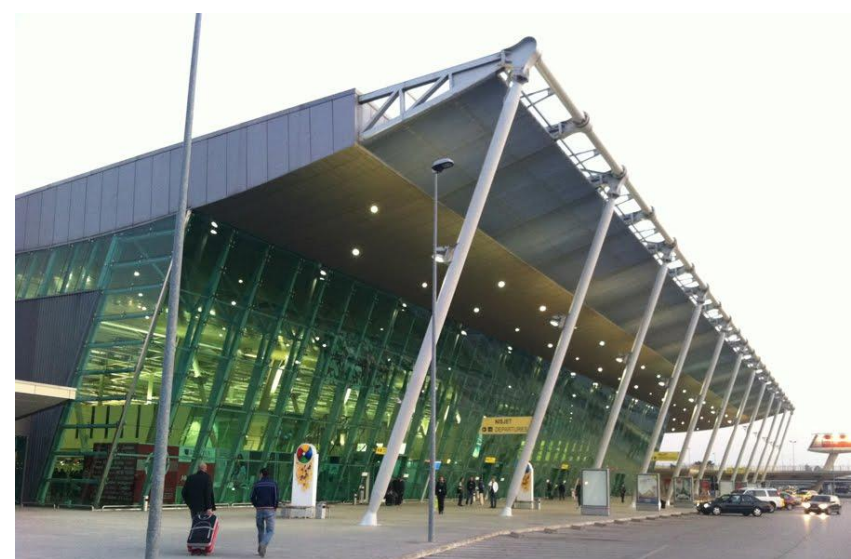

Figure 21: Tirana International Airport TIA / Hintan Associates [30]

Opened in 2011, Tirana East Gate Mall (T.E.G.) were the first modern shopping center in Albania and one of the largest in the region. With an area of $50,000 \mathrm{~m}^{2}$ multi-use commercial development, T.E.G. offers visitors an array of features including 
shopping, restaurants, and social/entertainment venues such as a cinema complex (cineplex) and fitness facility (Figure 22).

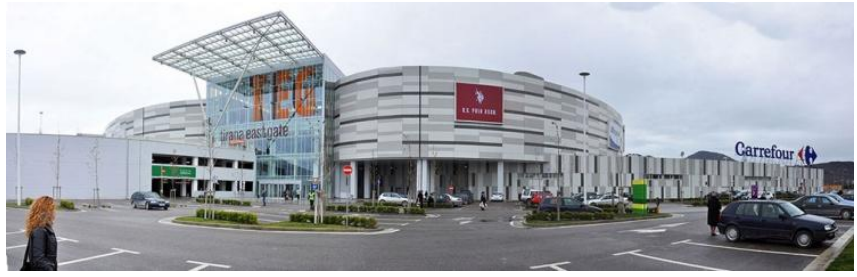

Figure 22: Tirana East Gate (TEG)/LAGUARDA. LOW, Texas, USA [9]

The Renovation of National Bank of Albania Headquarter building by Petreschi Architects was one of successful intervention that aimed to protect a building part of cultural heritage and adding new architecture in harmony with the existing one (Figure 23).

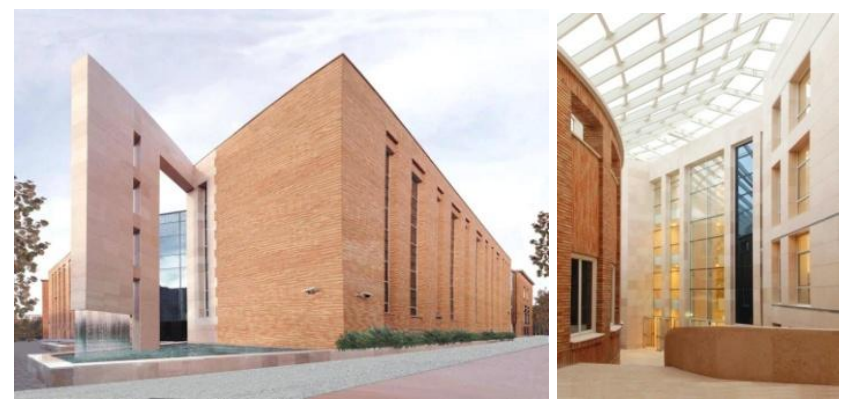

Figure 23: Bank of Albania HQ Renovation/Petreschi Architects [31]

Unrealized winning competition projects have been: "The Parliament of the Republic of Albania" Coop Himmelb(I)bau (Figure 24), "Mosque of Tirana" Bjarke Ingels Group - BIG (Figure 25), Tower in the Junction of "Durresi" street with "Kavaja" street of Henning Larsens Tegnestue, "Tirana Rocks" of MVRDV (Figure 26), Intermodal Terminal of Tirana proposal of Ital-Ferr S.p.A (Figure 27), etc. These proposals expressed the latest trends in contemporary architecture but mostly have been abandoned because of contextual solutions and the political changes. The last proposal for the Intermodal Terminal of Tirana is under the discussion by the new administration of the city.

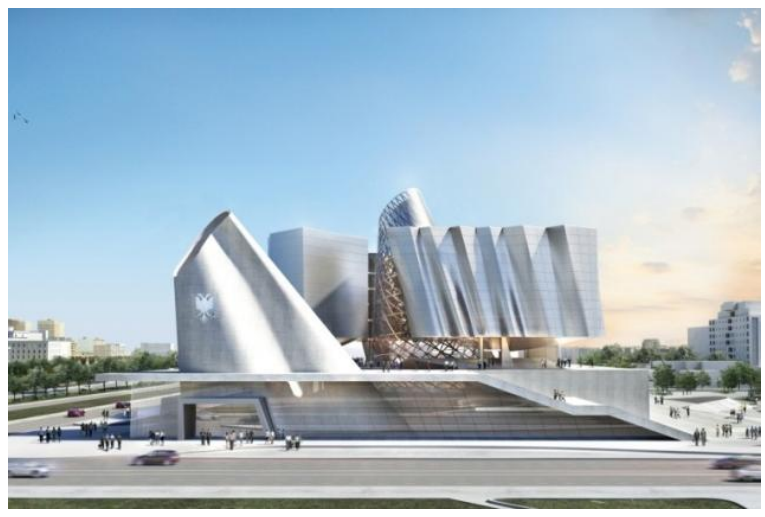

Figure 24: The Parliament of the Republic of Albania/Coop Himmelb(I)bau [32]

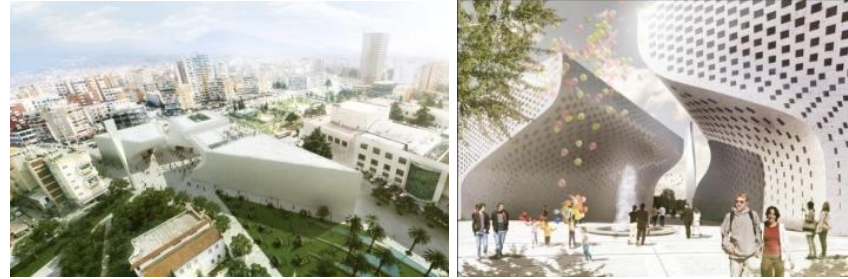

Figure 25: Mosque of Tirana/Bjarke Ingels Group - BIG [33]

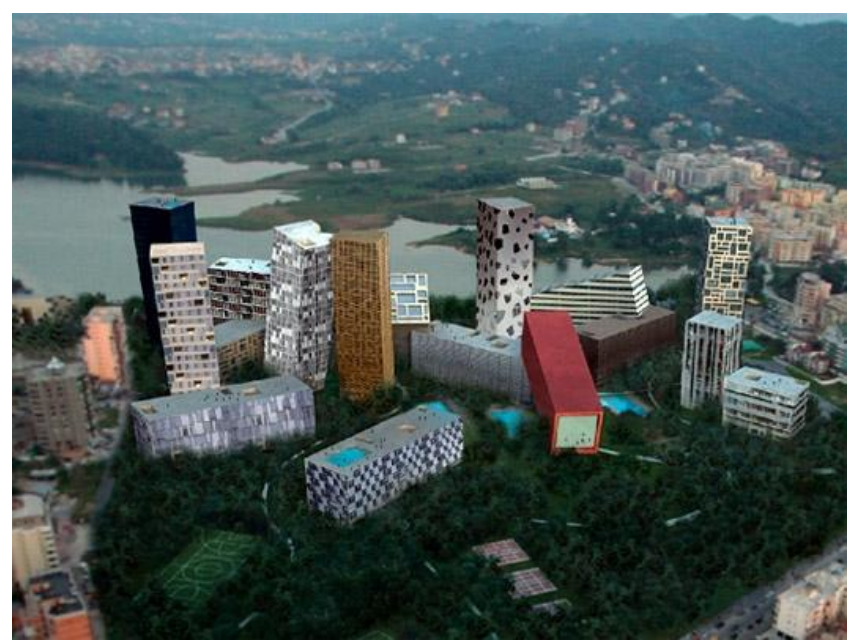

Figure 26: Tirana Rocks/MVRDV [26]

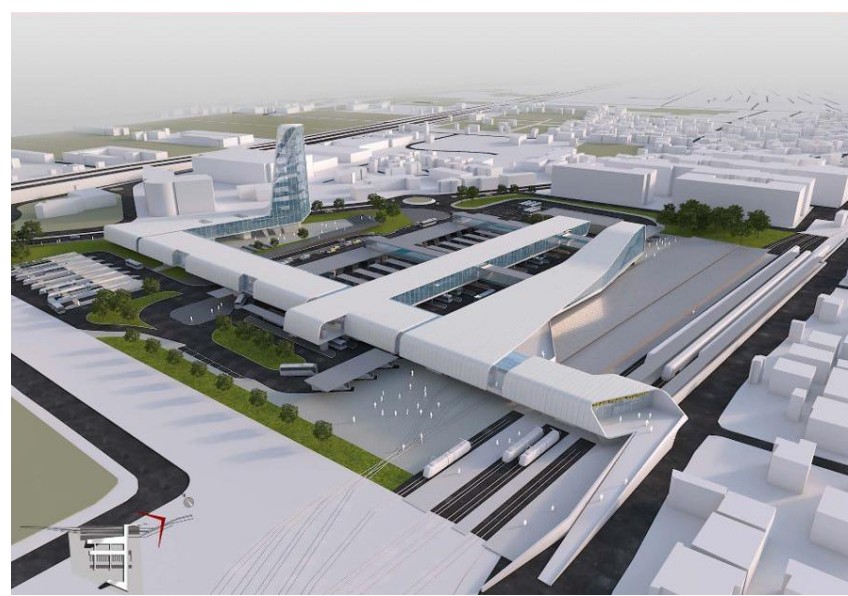

Figure 27: Intermodal Terminal of Tirana / Ital-Ferr S.p.A [34]

In 2013, the new general Master plan of Tirana was approved by the Mayer Lulëzim Basha. Finally, Tirana has a new plan approved after a long period of transition. It was a work of Municipality of Tirana in the cooperation with academia (Polytechnic University of Tirana), specialized institutions, NGOs and the community. The polycentric Tirana was one of the main achievements of this plan. In the framework of this plan an international competition for "Building Tirana's Green Future" chose the Grimshaw Architects to master-plan the Central Boulevard of Albania's capital city, Tirana.

The plan proposes a robust sequence of public spaces threaded along the boulevard (Figure 
28). The urban design focuses on the creation of Urban Living Rooms, which reflect the Mediterranean outdoor culture of Tirana. The new network of public spaces will change the perception of the city rendering more open and accessible. The river park is structured around the same concept of sequencing spaces which are open and green [35].

a)
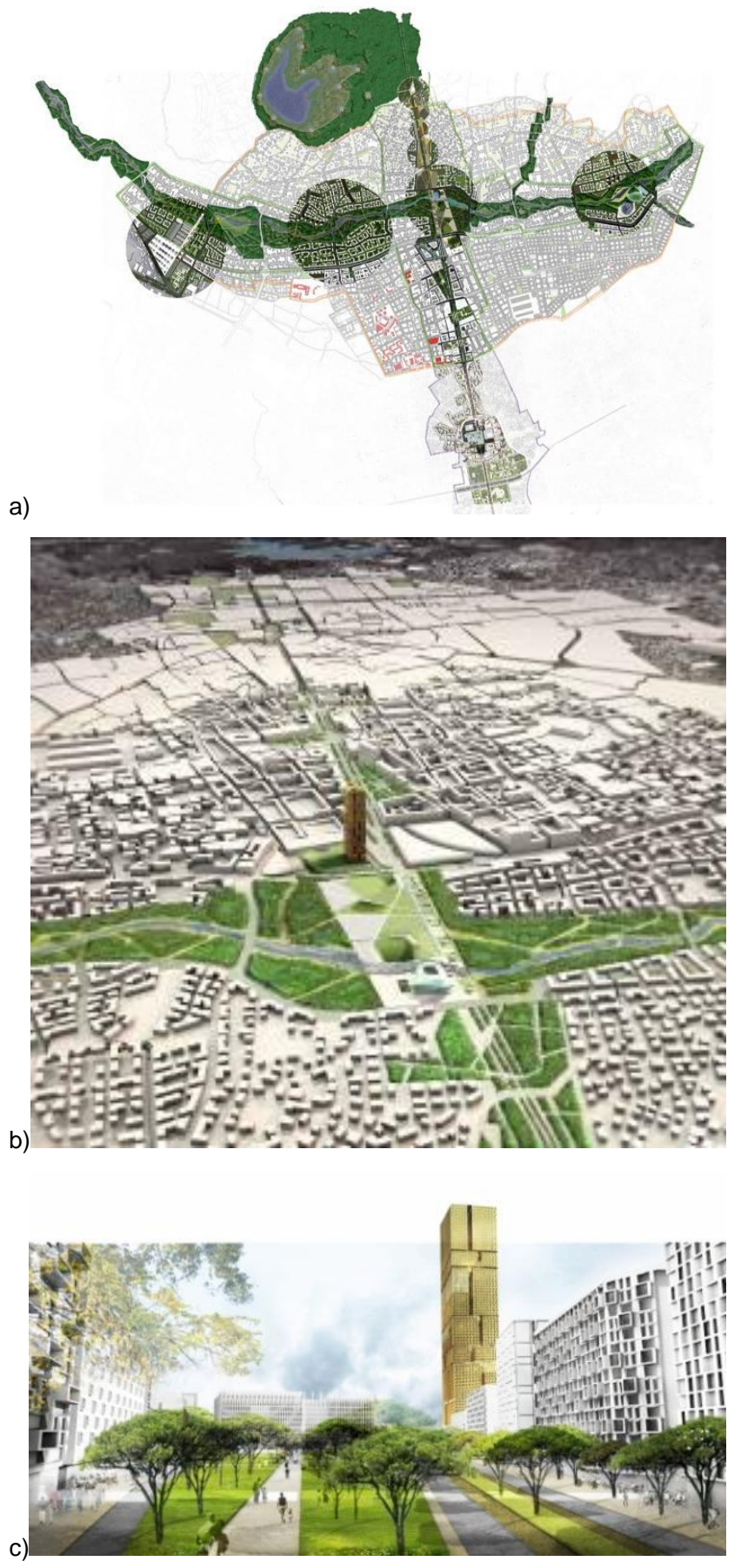

Figure 28: a) Tirana general Master-plan; b) c) Prospective view/Grimshaw [36, 37]

Atelier Albania the laboratory unit of the National Territorial Planning Agency mandated by the Ministry of Urban Development and Tourism and the Office of the Prime Minister of Albania, since 2013 is launching international design competitions promoting innovative practices in architecture and planning [38]. Recently two other competitions for Tirana city were "Campus Master Plan, Constructing New Student Residences and Rehabilitating the Existing Ones" wined by Baukuh+List (Figure 29) and "The Master Plan of the entrance to the Tirana Park and architectural project ideas for two public buildings: the Public Service Center and the General Directorate of the State Police, Tirana, Albania" wined by Thomas Reynaud and BuildingBuilding (Figure 30).

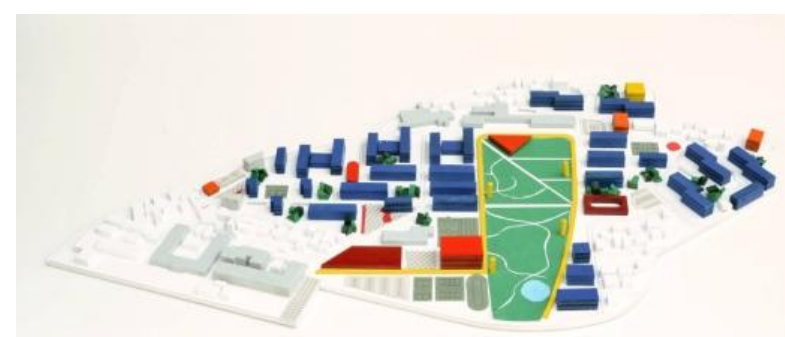

a)

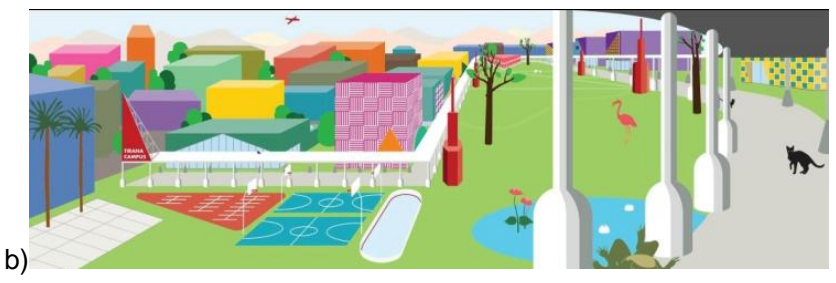

Figure 29: a) Student City Campus Master-Plan; b) Prospective view/Baukuh - List - Abkons - F\&M Ingegneria - Space Caviar Boda [39]

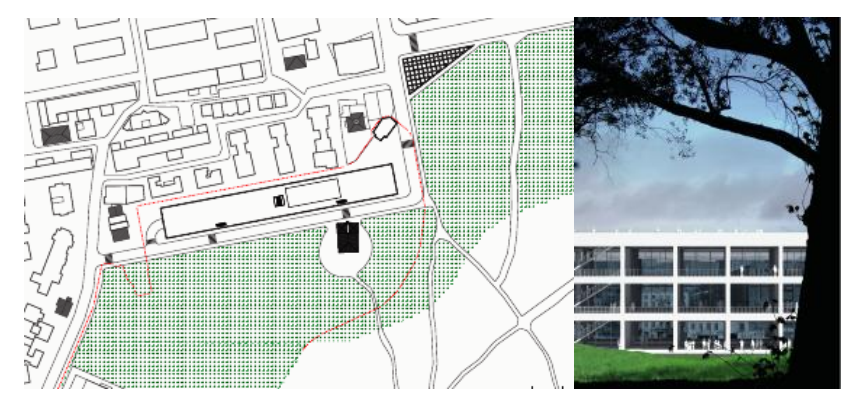

Figure 30: The Master Plan of the entrance to the Tirana Park / Thomas Reynaud / BuildingBuilding + UHO + Elias Guenoun + David Levain + Simon Boudvin + VPEAS + Bollinger+Grohmann [39]

Participation in these international competitions has been general with the invited foreign architecture studios in cooperation with some local studios. The competitions, in general, have brought innovation in contemporary architecture in Albania. Innovative ideas are expressed in the design of different typologies buildings associated with the aspect of content, shape, and size, functionality, aesthetics, spatial formulation, and technology. But, although the proposed facilities or those generated in the largest number are achievements of the various architectural typologies some of them display problems of the quality, the quantity of construction as 
well as low possibility for realizing international projects because of economic crises.

\section{Conclusions}

One of the most important general conclusions of this paper is that the change of system that affected Albania after the 90s inevitably was reflected in the rapid development of architecture and urban development. The transition period has affected and continues to affect the quality, amount, shape, size, as well as the functionality and aesthetics of construction.

The modern architecture began to consolidate with innovative ideas of young architects who came into contact with Western cultural trends and currents. Other imputes of modernism and internationalization was coming from abroad.

The competitions, in general, have brought innovation in contemporary architecture in Albania. Innovative ideas are expressed in the design of different building typologies associated with the aspect of content, shape, and size, functionality, aesthetics, spatial formulation and technology.

Although the achievements presented by international competitions some problems are arising as:

- Internationalization of the architecture of the city at the expense of urban and architectural heritage.

- Some projects display problems of the right report with the contexts proposed and existing situation of the city.

- The lack of respect to plans, planning legislation and regulations regarding building density and coefficients that in many cases are sanctioned in the drafting of the design task.

- The high cost of construction that not fit to the real estate market and the city's economy.

- Participation in these competitions has been general with the invited foreign architecture studios, denied sometimes participation of Albanian architects.

The last economic crisis that engulfed Albania reflected in fields of planning, architecture and all forms of creativity. It has affected and still affects the quality, the quantity of construction as well as low possibility for realizing with standards international design projects.

\section{References}

1. Lulo K, Tummers K. Architecture and Urban Planning. History of Albanian Architecture Model, 2012. [online] at
www.seda.org.al/download/i/.../2.3-Architecture.pdf [accessed on 10/10/2015].

2. Gazeta Shekulli. Vetëdeklarimet, në Shqipëri u bënë 427 mijë ndërtime pa leje në 23 vite. Gazeta Shekulli 13, Shkurt 2015. Available: http://www.shekulli.com.al/p.php?id=216651 [accessed on 06/10/2015].

3. Aliaj B, Lulo K, Myftiu G. Tirana, the challenge of urban development, History of architecture of urban development. Tirana, March 2003: p.66.

4. Lufi A. Coscienca della realtá. AND Revista di Architetture, citta e architetti, Tirana, April 2008.

5. Faja E. Institucioni i kryearkitektit te Tiranes. In Kush e drejton urbanistikën Shqiptare. Përmbledhje artikujsh kritik, UFO press, 1991-2008: p.12.

6. Faja E. Gjeneza e Arkitekturës moderne dhe e realizmit socialist në Shqipëri, në vitet 1945-1980". Gazeta 55, date 16/12/2010.

Available: http://gazeta55.al/gjeneza-e-arkitektures-moderne-dhe-erealizmit-socialist-ne-shqiperi-ne-vitet-1945-1980/[accessed on 06/10/2015].

7. Kolevica P. Arkitektura dhe Diktatura. Shtëpia Botuese MARIN BARLETI, Tirane 1997:pp. 66-75.

8. Shkreli A. Pallati me Kuba - disidencë mbrujtur në tulla. GazetaShqip, 28 Korrik 2012. Available: http://www.gazeta-

shqip.com/lajme/2012/07/28/pallati-me-kuba-disidence-mbrujtur-netulla/[accessed on 08/10/2015].

\section{Author.}

10. Shkreli A. Tipo \& molteplicita. AND Revista di Architetture, citta e architetti, April 2008: p.44-45.

11. Vokshi A. Altri orizzonti, verso una nuova architettura albanese. AND Revista di Architetture, citta e architetti, April 2008: p.20-21.

12. Tamburelli PP. New Tirana, "Domus", 894, July-August 2006 p.88.

13. Bulleri A. Tirana Contemporaneità sospesa / Suspended Contemporaneity. Quodlibet, 2012.

14. Aliaj B. Edhe njëherë për projektin Ti-Rama. Tirana dhe Imagjinata Urbane, Forum A+P Periodik Shkencor per Arkitekturën dhe Planifikimin Urban, 2012: p. 66-70.

15. Zacks S. The Building as Canvas. METROPOLIS MAGAZINE/November 2005. Available:

http://www.metropolismag.com/November-2005/The-Building-asCanvas/ [accessed on 20/10/2015]

16. Plani-Urbanistik-i-Tiranes. Available:

http://www.tirana.gov.al/sq/Plani-Urbanistik-i-Tiranes/Njihu-meplanin-rregullues-5086 [accessed on 24/09/2015].

17. Fagu E. Archive, 2016.

18. Luarasi S. Archive, 2016

19. E-architect. School Building in Albania, 2006.

Available:http://www.e-architect.co.uk/albania/ate-pjeter-meshkalla [accessed on 20/10/2015].

20. Raça Studio. Archive, 2016

21. B \& L Studio. Archive, 2016

22. Bregu V. Archive, 2016

23. Available: http://shitjet.gener2.al/sq/project/projektiliqeni/[accessed on 26/10/2015].

24. Available: http://www.albanianchildren.org[accessed on 18/10/2015]

25. Smart Studio. Archive, 2016.

26. Available: http://www.skyscrapercity.com [accessed on 18/10/2015]

27. Available: http://www.archea.it [accessed on 20/10/2015]

28. Available: http://www.contact.com [accessed on 20/10/2015].

29. Available: http://www.architravel.com [accessed on 16/10/2015].

30. Available: http://www.tirana-airport.com [accessed on 
16/10/2015].

31. Available: http://www.marchopetreschi.com [accessed on 18/10/2015].

32. Available: http://www.coop-himmelblau.at [accessed on 20/10/2015].

33. Available: http://www.archiscene.net [accessed on 16/10/2015].

34. Available: http://acp.al/projects/119/Terminali-Multimodal/ [accessed on 26/10/2015].

35. GrimShaw Tirana Master Plan. Available: http://grimshawarchitects.com/project/tirana-masterplan/[accessed on 20/10/2015].

36. Waite R. Grimshaw scoops Tirana boulevard contest. Architects journal, 12 June, 2013. Available:

http://www.architectsjournal.co.uk/home/grimshaw-scoops-tiranaboulevard-contest/8630668. article [accessed on 20/10/2015].

37. Waite R. Grimshaw unveils new Tirana images. Architects journal, 12 JUNE, 2013. Available:

http://www.architectsjournal.co.uk/news/daily-news/grimshawunveils-new-tirana-images/8649206.article [accessed on 18/10/2015].

38. Agjensia Kombetare e Planifikimit te Tetrritorit. 2015. Available: http://www.planifikimi.gov.al/?q=content/atelier-albania [accessed on 26/10/2015].

39. Available: http://competitions. planifikimi.gov.al/studentcity/ [accessed on 26/10/2015]. 